\title{
Stem Cell Based Bone Tissue Engineering
}

\author{
Lauren Vernon, Lee Kaplan \\ and Chun-Yuh Charles Huang \\ University of Miami, Coral Gables, FL
}

USA

\section{Introduction}

Regenerative tissue engineering is defined as the combination of living cells and biocompatible scaffolds to generate a biologic substitute capable of sustaining itself and integrating with functional native tissue. By engineering and delivering tissues and/ or cells capable of replacing damaged tissue, regenerative medicine offers the potential for the treatment and possibly curing of debilitating diseases. Optimized methods for improving the function and maturation of engineered cellular constructs to produce constructs with near-native tissue properties are necessary to enable translation to clinically useful therapies.

In regenerative tissue engineering, there are many issues to consider in the creation of a functional, implantable replacement tissue. Most importantly, there must be an easily accessible, readily abundant cell source with the capacity to express the desired tissues' phenotype, and a biocompatible inert scaffold to deliver the cells to the damaged region. Currently, there are many regenerative tissue engineering studies in preclinical and clinical testing using stem cells.

What are stem cells? In the body there are many different types of cells, each specialized for a specific distinct function. These cells are committed to a specific lineage and function, for example cardiomyocytes in the heart, chondrocytes in cartilage, and osteoblasts in bone. Immature progenitor cells called stem cells are not lineage specific. Stem cells have the ability to differentiate into many different kinds of cells. Differentiation is the process by which an unspecialized parent or progenitor cell gives rise to a specialized daughter cell; this process occurs in stages with the cell becoming increasingly specialized with each step. At fertilization, a zygote is formed containing totipotent stem cells which can differentiate into any cell type. After a few days, the blastocyst develops with an outer layer and inner cell mass. Cells from the inner cell mass are pluripotent stem cells and can become cells from all of the germ layers (ectoderm, mesoderm, endoderm). As the embryo continues to develop, the cells become increasingly specialized and begin to commit to specific cell lineages (as seen in Figure 1 below). Cells committed to a specific cell type and function lose their stemness; however, a population of undifferentiated stem cells remains amongst the differentiated cells. These adult stem cells can be harvested from various tissues in the body and then cultured invitro. Under specific culture conditions, those undifferentiated cells can be directed towards specific lineages, providing us with a potentially limitless supply of tissue. 


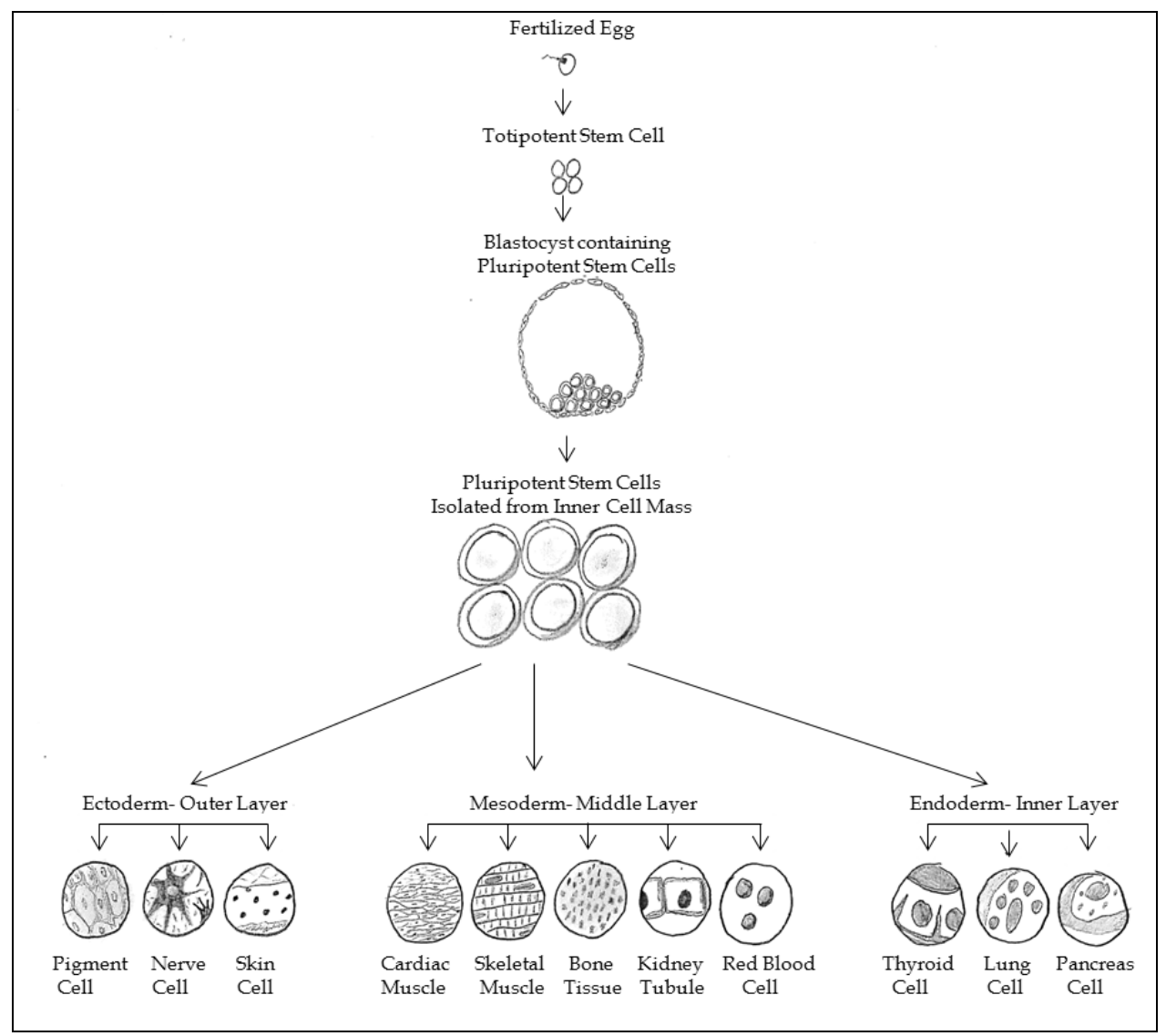

Fig. 1. Stem cell differentiation diagram

There are two parameters used to assess the tissue engineering potential of stem cells: proliferation rate and differentiation potential. The cells' proliferation rate is the speed at which the cells divide. The cell differentiation potential determines whether the cell line is capable of developing into specific lineages, in this case osteogenic. These components are critical, because if cells are not expanding at a specific rate and are not differentiating towards the lineage desired, the engineered tissue will not mirror the characteristics of native tissue and serve the desired function.

\section{Bone properties}

\subsection{Bone composition}

Bone is a multifunctional organ that plays many important roles in the body, such as providing protection and structure (shape) among others. Despite its relatively simple outer 
appearance, bone is not a solid homogenous tissue. Bone is made up of solid material with spaces between its hard elements. The outer smooth portion of the bone is compact or cortical bone ( $80 \%$ of bone), and the inner spongy part of the bone is trabecular bone $(20 \%$ of bone). Furthermore, within those regions are different types of cells making up the cellular structure of the bone itself: osteoblasts, osteocytes, and osteoclasts. Osteoblasts are bone forming cells and are the direct descendants of osteoprogenitor cells (Kneser et al., 2006; Buckwalter \& Hunziker, 1996; Heinegard \& Oldberg, 1989). They produce a protein mixture called osteoid which mineralizes to form solid bone, and produce alkaline phosphatase (ALP), a key enzyme in bone mineralization. Osteocytes are descendants of osteoblasts which migrate into the bone matrix forming lacunae spaces. Osteocytes are responsible for bone formation, matrix maintenance, and calcium homeostasis. Osteoclasts are the bone's absorption cells. These are the cells that are responsible for bone remodeling and the overall decrease in bone mineral density (Shier et al., 2002). Bone is a connective tissue which provides structural support and protects the vital organs while allowing for movement. Bone is composed of a type I collagen matrix embedded with calcium, phosphorous, sodium, magnesium and other ions necessary for homeostasis in the body. The extracellular components of bone (organic matrix and minerals) combine to strengthen the bone, giving it the ability to withstand mechanical stresses.

\subsection{Bone formation and maturation in vivo}

Within the body there are two main mechanisms of bone formation and growth, intramembranous ossification for flat bones and endochondral ossification for long bones. In intramembranous ossification, connective tissue occupies the place of the future bone and is slowly replaced as ossification centers develop, calcification occurs, and the trabeculae forms. In endochondral ossification, also referred to as intracartilaginous ossification, a cartilage model template structure is used on which the primary and secondary ossification centers are established. When bone is finished forming, remnant articular cartilage often remains on the end of the bones. Although induced tissue engineering differs from either pathway, in vitro osteogenic differentiation more accurately mirrors the intramembranous ossification process.

\subsection{Bone repair}

Following injury, a healing cascade is triggered to restore the tissue's original state. This healing cascade occurs in three phases: inflammatory, repair, and remodeling (as seen in Figure 2). Briefly, the inflammatory phase results in hematoma formation as fibroblasts and cells from the inflammatory cascade (macrophages, monocytes, lymphocytes etc.) migrate into the injury site (hours to days). In the repair phase, collagen fibers and mineralized osteoid combine to form a soft callus around the injury site (4-6 weeks). As the callus ossifies it forms a disorganized structure known as woven bone. During the remodeling phase the disorganized woven bone is replaced by highly organized sheets of parallel collagen fibers called lamellar bone. This restructuring occurs in response to mechanical stresses signaled to the osteocytes and subsequently osteoclasts and osteoblasts (Kneser et al., 2006; Probst \& Spiegel, 1997). The repair mechanism continues to change the bone properties through constant remodeling via bone deposition and resorption (Kneser et al., 2006; Kalfas, 2001). 
Bone tissue can be damaged due to injury or disease. Following a traumatic event, fractured bones can be aligned by a physician, and the damaged area can heal and repair. However, bones that are damaged due to disease are not as successful at self-restoration as bones set by a physician and do not have the ability to repair and remodel properly.

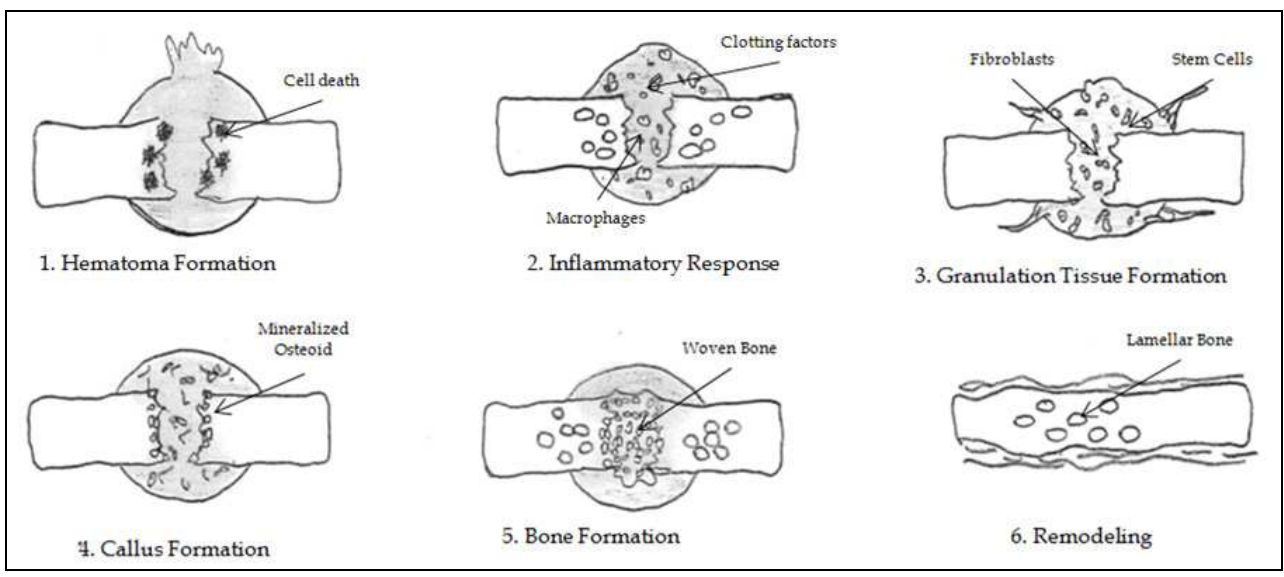

Fig. 2. Bone repair mechanism

\subsection{Current treatments for damaged bone}

\subsubsection{Bone grafts}

Bone grafts are used to enhance bone healing in specific injury zones. There are a number of factors to take into consideration when selecting a bone graft, such as osteoinductiveness, osteoconductiveness, mechanical stability, quality of transplantable bone, and preservation techniques, as well as implantation site considerations such as local disease and biomechanical properties (Khan, et al., 2005). Osteoconductive grafts function as a scaffold for native bone cells adjacent to the graft to migrate into and form new bone. Osteoinductive grafts serve to actively stimulate progenitor cells to differentiate into osteoblasts. A graft can be considered osteogenic if it already contains osteoblasts. The main types of grafts currently being utilized are autografts, allografts, xenografts, and synthetic grafts.

Conventionally, autografts are the most effective grafts since they are harvested from the patient's own body, usually from the iliac crest, fibula, ribs, or mandible. Although using the patient's own bone reduces the risk of rejection and disease transfer, it also increases pain, since the donor graft must be harvested surgically. In addition to the risk of infection from harvesting the patient's own bone, the process can be extremely painful, and as with all surgeries, there is always the risk of complications. Autografts are osteoconductive, osteoinductive, and osteogenic, which is what makes them the ideal choice (Burchardt, 1983). However, the amount of bone available for autografts is limited and the procedure creates a secondary healing site. 
Allografts, on the other hand, are also natural human bone grafts, but unlike autografts which are harvested from the patient's own body, allografts are harvested from an external donor. Although the allograft eliminates the need for an additional surgery on the recipient, they also do not have the immunogenic properties of the autograft, and the risk of rejection increases (Mankin et al., 2005). Depending on how the allograft was harvested, stored, and treated, it will have osteoconductive properties, but may or may not have osteoinductive properties, and will not have any osteogenic properties (Mankin et al., 2005). For example, freeze-drying samples reduces antigenicity while maintaining biomechanical properties.

Xenografts are grafts that are harvested from another species and are stripped down to just their calcium matrix. These grafts are osteoconductive but not osteoinductive or osteogenic. Due to their limited surface properties, synthetic grafts are a preferred alternative.

Synthetic grafts are artificial bone grafts that can be made of biologically active materials such as ceramics, bioglasses, or even calcium sulphate. These grafts can be functionalized with growth factors to increase their osteoconductive and osteoinductive abilities. Along those lines, engineering a replacement bone tissue from the patients' own autologous stem cells seems to be a more practical solution. An explanation of various biomaterials that are used to make synthetic grafts will be explained later in the scaffolds section of the chapter (Section 5).

\subsubsection{Bone bracing}

In some cases damaged bones are incapable of properly repairing and remodelling; therefore, additional steps such as utilizing bone bracing can be taken to aid the reconstruction. These approaches include both surgical and non-surgical methods of immobilizing the injured region allowing bone repair to begin.

Non-surgical alternatives such as external casts and bracing are viable alternatives in cases with fracture displacements less than $2 \mathrm{~mm}$. This is the preferable method for bone healing, as it is non-invasive and minimizes risk of infection. Regenerative tissue engineering is not required in these cases and may not be applicable for these cases.

Surgical approaches, such as open reduction internal fixation in which bones are set and held in place by nails, screws, or plates to guide and facilitate the healing process. Unfortunately, as with an surgical option, there is an increased risk of infection; however, surgical approaches are necessary in fracture displacements exceeding $2 \mathrm{~mm}$. In cases where surgery is required, regenerative tissue engineering may provide the materials necessary for creating bone in these voids, reducing healing time and increasing bone strength. Usually these fixation devices are metals, which provide immediate mechanical support; however, metals have poor integration into the bone and can cause re-injury and implant failure over time, therefore, alternative approaches are being investigated.

\subsubsection{Biomaterials and alternative approaches}

In some cases, bones that are damaged are unable to repair and remodel properly and additional steps can be taken to aid the reconstruction, such as utilizing bone cements. In other cases, joint replacement surgery is needed to repair areas where the cartilage has been destroyed and the bones are exposed. When this occurs, a prosthetic joint is drilled into the 
bone and can either be cemented in with a polymer bone cement or left un-cemented. Traditionally, acrylate-based bone cements have been used for their high mechanical stability (Muh, et al., 2002; Lewis, 1997). When the bone is cemented in place, the recovery time is much quicker than when left un-cemented. On the other hand, when left uncemented, the natural bone can grow into the porous surfaces of the implant, making it stronger over time. This means that the implant is less likely to fail, which would require an additional surgery. Therefore, osteoinductive alternative, such as calcium phosphate and apatite-based bone cements, have been investigated. Although osteoinductivity is increased, these cements are also biodegradable, therefore, their mechanical strength decreases over time (Cassidy, et al., 2003; Zijderveld et al., 2005).

In regenerative tissue engineering, living cells and biocompatible scaffolds are combined to generate biologic substitutes capable of sustaining themselves and mimicking functional native bone. This is accomplished by incorporating osteoinductive and osteoconductive molecules into the scaffold, as explained in the scaffolds section of the chapter (Section 5).

\section{Bone tissue engineering with stem cells}

Cells are the basic functional and structural unit in the body. All cells in the body have the same primary DNA sequence; however, changes in phenotypic expression result in cells with a variety of shapes and sizes which correlate to the function of each cell. This diversity comes at a cost; in general, once a cell has differentiated into a specific lineage, it cannot revert back to its primordial state (exceptions, ex: cancer and induced pluripotent stem cells). Stem cells, however, are undifferentiated cells (a characteristic referred to as stemness). These cells have not committed to any specific lineage and can give rise to a variety of specialized cell types depending on their plasticity. A cell's plasticity is its ability or inability to differentiate into any of the germ layers (ectoderm, mesoderm, endoderm) based on culture conditions.

In general, differentiated cells have a limited number of population doublings over the course of a person's life (approximately 80-90 times) (Fox, 2001). During telophase of mitosis, the telomere region of the chromosomes lose some of the DNA sequences, approximately $50-100$ base pairs (Fox, 2001). Stem cells (as well as germinal cells and cancer cells) produce telomerase, an enzyme which duplicates the telomere DNA; therefore, stem cells are capable of dividing and self-renewal for long periods of time and are often referred to as immortal. Furthermore, when stem cells divide, they can undergo either symmetric division, producing two daughter stem cells identical to the parent cell, or by asymmetric division, producing one daughter stem cell and one daughter progenitor cell.

Stem cell biology has become an important topic in regenerative tissue engineering, specifically the use of multipotent mesenchymal stem cells (MSCs). Although embryonic stem cells are considered the gold standard in stem cell research, bone-marrow derived mesenchymal stem cells (BM-MSCs) are the most researched postnatal stem cells. Multipotent postnatal stem cells have been isolated from numerous tissues throughout the body such as bone marrow, adipose tissue, muscle, dental tissue, umbilical cord, etc. (Campagnoli et al., 2001; Zuk et al., 2001; Gronthos et al., 2000; Miura, et al., 2003; Seo, et al., 2004; Schugar, et al., 2009; Young, et al., 2001).These stem cells are capable of differentiating 
into a variety of cell lineages, including bone. Therefore, transplanting a patient's own stem cells may be a potential treatment for repairing bone defects. This chapter details progress made to date in the osteogenic differentiation potential of these cell lines and their potential use in repairing bone defects.

\subsection{Embryonic stem cells}

At fertilization, a zygote is formed that contains totipotent cells which are cells with the ability to form any of the 200+ cell types in the body and the cells of the placenta. After four days (about 40-150 cells), the blastocyst develops. The blastocyst is identifiable by the development of the outer trophoblastic layer and inner cell mass (ICM). The outer layer of cells becomes the placenta and other tissues necessary for fetal development and survival. The inner cell mass forms the fetus and contains pluripotent cells that go on to form all the tissues in the human body. The use of pluripotent embryonic stem cells in regenerative therapies is an attractive option with the ability to give rise to tissues from the three germ layers, including the mesodermal lineages such as bone.

Both totipotent and pluripotent (blastocyst) embryonic stem cells (ESCs) (Figure 1) are considered the gold standard in stem cells; however, controversy and debate surround ESCs. Despite the ethical debate, clinical benefits from ESCs could be numerous, but more work is needed before they can be used for clinical applications. In addition to the ethical considerations, additional concerns for using ESCs include the potential for teratoma formation when implanted in vivo.

\subsubsection{Fetal stem cells}

Fetal stem cells are cells obtained from an unborn fetus when the fetus has developed enough that cellular extraction does not cause fetal death. These cells are pluripotent and responsible for the development of all tissues before birth. Unlike ESCs, fetal stem cells can be obtained without completely destroying the embryo, allowing the fetus to develop into a full-term baby (Biswas \& Hutchins, 2007). However, the effect of removing cells during fetal development is unknown, and fetal stem cells have many of the same ethical considerations as ESCs. These pluripotent cells can undergo osteogenic differentiation, making them a valid source for regenerative bone tissue engineering.

\subsection{Bone marrow-derived mesenchymal stem cells}

BM-MSCs are a heterogeneous population of multipotent cells. BM-MSCs are capable of differentiating into multiple lineages in vitro including the osteogenic lineage. BM-MSCs are a popular source of autologous adult stem cells, because they are readily available. However, the extraction procedure is extremely painful and invasive. In addition to their differentiation potential, BM-MSCs can be used directly to positively influence the repair mechanism and healing of cardiac tissue following a myocardial infarction (Amado, et al., 2005). Impressively, this is accomplished with BM-MSCs from living donor tissue, and the BM-MSCs inherent immunogenic characteristics limit the recipient's immune response to the foreign cells. This makes BM-MSCs a great source for regenerative tissue engineering applications, because they can be extracted, expanded, and banked, making them readily available when they are needed. 


\subsection{Umbilical cord blood stem cells}

Umbilical cord blood (UCB) stem cells are cells found in the umbilical cord blood of a newborn baby, and they share the newborn's genetic material. UCB cells can be obtained with higher cell yields and without the pain and morbidity associated with BM-MSC acquisition (G. Huang et al., 2009). These cells are multiotent, hematopoietic stem cells and can differentiate into various cell lines including the osteogenic lineage (Liu, et al., 2011). In addition to their differentiation potential, UCB cells can be used directly to successfully treat leukemia, lymphoma, myelodysplasia, apalstic anemia, hemoglobinpathies, metabolic diseases, and immunodeficiencies (Brunstein et al., 2007; Ballen, et al., 2008). UCB cells have similar morphologic and immunophenotypic properties to BM-MSCs (Kern et al., 2006); however, UCBs form fewer colonies than BM-MSCs, and UCB cells form have a high proliferative capacity (G. Huang et al., 2009), perhaps due to their age and harvest location. Until recently, umbilical cords were discarded at birth, so most individuals have lost their source for autologous UCB cells. Now, parents are given the option of donating their newborn's UCB cells to public storage banks or saving them in a private bank for autologous or family member use.

\subsection{Stem cells from dental tissues}

Physiological similarities between dental-tissue and bone make dental-derived progenitor cells a logical source of stem cells for osteogenic differentiation. Cells from dental tissues are called ectomesenchyme cells, because they are remnant tissues derived from the cranial neural crest. Cranial neural crest cells are capable of differentiating into bone, cartilage, and ligament during embryonic development; therefore, cells derived from them possess similar abilities (Chai, et al., 2000; Huysseune \& Thesleff, 2004; Le Douarin et al., 2004).

\subsubsection{Stem cells from human exfoliated deciduous teeth}

SHED (stem cells from human exfoliated deciduous teeth) are multipotent stem cells isolated from the remnant pulp of deciduous (baby) teeth (Miura, et al., 2003). Similar to the umbilical cord, deciduous teeth offer the opportunity for painlessly obtaining primordial cells that would otherwise have been thrown away. SHED proliferate faster than BM-MSCs, can undergo osteogenic differentiation, and express ESC markers (Kerkis, et al., 2006; Miura, et al., 2003). Furthermore, SHED appear to have osteoinductive properties, meaning they induce new bone formation by recruiting osteogenic host cells into an osteoinductive template (Miura, et al., 2003). This approach is already being used to repair critical-size calvarial defects in mice (Seo, et al., 2007).

\subsubsection{Dental pulp stem cells}

Similar to SHED, dental pulp stem cells (DPSCs) are heterogeneous populations of cells isolated from the human dental pulp of mature teeth. Within a colony of these multipotent cells, various cell morphologies are expressed. DPSCs proliferate faster than BM-MSCs but not as fast as SHED (Miura, et al., 2003) and are capable of differentiating into various lineages including osteogenic (Laino, et al., 2005). Interestingly, DPSCs cultured on dentin differentiate into odontoblast-like cells (Batouli, et al., 2003), suggesting that DPSCs are pre-differentiated towards soft tissue repair or even bone tissue interfaces, but not osteogenesis. 


\subsubsection{Periodontal ligament stem cells}

Heterogeneous populations of multipotent stem cells (PDLSCs) have also been extracted from the periodontal ligament, a descendant of the cranial neural crest. PDLs express several ESC markers and have an upregulated telomerase activity, suggesting similar differentiation abilities to ESCs (C. Huang et al., 2009). Similar to other dental tissues, PDLSCs are capable of undergoing osteogenic differentiation and express osteogenic characteristics (Seo, et al., 2004; Gay et al., 2007; Isaka, et al., 2001; C. Huang et al., 2009). Furthermore, PDLSCs that are implanted in periodontal injuries regenerated a periodontal ligament-like tissue while aiding in the bone regeneration itself (Seo, et al., 2004). This suggests that they would be a viable source for regenerative bone tissue engineering.

\subsection{Adipose tissue-derived stem cells}

Adipose tissue-derived stem cells (ASCs) are multipotent cells located in fat that can differentiate into various cell lines including the osteogenic lineage (Levi \& Longaker, 2011; Wagner, et al., 2005). ASCs can be isolated from the lipoaspirate usually discarded from liposuction treatments. ASCs have been shown to not only undergo osteogenesis, but have actually been used to heal critical-size defects in mice (Cowan, et al., 2004). Furthermore, ASCs promote angiogenesis (new blood vessel formation), which can be crucial for engineered scaffolds to properly integrate with native tissue (Schroeder \& Mosheiff, 2011; Kim Y. , et al., 2007).

\subsection{Induced pluripotent stem cells}

As mentioned before, adult stem cells can be harvested from various tissues in the body and then, under specific culture conditions, directed towards specific lineages, thereby providing us with a potentially limitless supply of tissue. In general, ESCs are considered to be the gold standard in stem cell research due to their true pluripotency, and all other stem cells are measured in comparison. However, there are many ethical issues surrounding ESCs, most notably their source and the debate of whether or not the method used for the isolation of ESCs is murder. These ethical dilemmas and political restrictions on ESC use led researchers to investigate methods of reverting differentiated somatic cells back into their primordial pluripotent state. These reverted cells are called induced pluripotent stem (iPS) cells.

One of the earliest techniques for creating iPS cells was by retrovirus transduction of specific transcription factors to promote ESC-like characteristics and ultimately create a line of pluripotent adult stem cells (Yu, et al., 2007; Takahashi, et al., 2007; Takahashi \& Yamanaka, 2006; Meissner et al., 2007; Okita et al., 2007). Once the iPS cells are generated, they are evaluated for ESC characteristics by RT-PCR, Western blot, telomerase detection, genomic sequencing, and immunohistochemistry. Most retrovirus transduction techniques use transcription factors that are naturally found up-regulated in ESCs. Once cells expressing ESC characteristics are identified (transcription factor transduction has a relatively low yield), the iPS cells' stemness must be evaluated, and the cells are tested for population clonogenicity, immortality, and pluripotency. Clonogenicity and immortality are evaluated by allowing the iPS cells to undergo significant population doublings. Next, the cells pluripotency is evaluated through in vitro culture and in vivo, and the cells are evaluated on their ability to differentiate 
into cells representing each of the germ layers. iPS cells represent a unique source for pluripotent adult stem cells which can serve as a source for generating patient-specific tissue for regenerative tissue engineering applications, such as repairing bone defects.

Unfortunately, many of the techniques that are used to induce the cells back into the pluripotent state have an extremely low yield, making the process both inefficient and costly. Furthermore, those same techniques use factors (such as viral vectors to transduce genes) which are not FDA approved. With those considerations in mind, research continues on traditional stem cells as well as iPS cells.

\subsection{Evaluating potency}

When selecting stem cells for regenerative tissue engineering applications, it is important to select cells that are capable of undergoing the necessary differentiation. To evaluate the potency of the cells, a variety of tests are performed, and specific factors are identified.

As mentioned before, telomerase activity in ESCs and some adult stem cells correlates with those cells ability to divide indefinitely (Heins, et al., 2004; Biswas \& Hutchins, 2007). As cells begin to differentiate into specialized cell lines, telomerase levels decrease and ultimately disappear. Therefore, the presence of telomerase is a good benchmark for evaluating the primordial state of a cell and is often found in cells with the most potency potential (totipotent and pluripotent cells) (Heins, et al., 2004; Thomason \& Marshall, 1998a; Biswas \& Hutchins, 2007; Odorico et al., 2001).

Another method of evaluating potency is to allow the cells to grow in culture without passaging. When the cells become confluent, contact inhibition allows for spontaneous differentiation, and the stem cells will randomly divide into various lineages, thereby establishing their ability to form cells from specific germ layers, from which potency can be determined (Heins, et al., 2004; Itskovitz-Eldor, et al., 2000). Similarly, cells that are grown in 3-D cell suspensions form aggregates of differentiated cells called embryoid bodies. Continued culture of these embryoid bodies results in the formation of various germ layer derivatives (Itskovitz-Eldor, et al., 2000).

Furthermore, teratoma formation can be used to determine a cell's potency. Teratoma formation occurs when undifferentiated stem cells are injected into severe combined immunodeficient (SCID) mice, and the cells form tumors consisting of a variety of cell types (Heins, et al., 2004; Thomson, et al., 1998b; Park, et al., 2003; Knoepfler, 2009).

Finally, specific surface marker expression has been identified for undifferentiated and differentiated tissue. Antigen analysis can reveal a cell's primordial state, suggesting its potency (Amit \& Itskovitz-Eldor, 2002; Knowles et al., 1978; Biswas \& Hutchins, 2007; Lebkowski, et al., 2001).

\section{Media formulations for osteogenic differentiation}

All cells in our body contain the exact same DNA sequence of genes; however, the genes that are activated depend on the function of each cell. Most cell types have genes that are specific to that cell type (due to its unique functionality). These genes are responsible for coding specific proteins that are necessary to retain cell function. When cells are changed 
from stem cells (no specific function) into osteoblasts (cells that make our bones), genes that are specific to bone are activated. When a gene is activated, RNA is synthesized (transcription), and corresponding proteins are produced (translation).

In culture, cells can be propagated or differentiated based on the culture media. Transplanted cells that have been pre-differentiated in vitro into the osteogenic lineage form bone-like tissues better than undifferentiated transplanted cells (Cowan, et al., 2005; Conjero, et al., 2006). Currently, there are two treatments that are being used in osteogenic differentiation, dexamethasone (DEX) and retinoic acid (RA) (Ogston et al., 2002). In addition, there are osteoinductive molecules that can be added to enhance bone formation such as bone morphogenic protein (BMP) and platelet derived growth factor. The exact intra-cellular mechanism through which these treatments stimulate osteogenic differentiation is unknown.

\subsection{Dexamethasone}

DEX is a synthetic glucocorticoid. Osteogenic differentiation occurs when stem cells are treated with DEX (Bielby et al., 2004; Pittenger, et al., 1999; C. Huang et al., 2009; Zuk, et al., 2001; Young, et al., 2001), resulting in mineral deposits when grown in monolayer (Gronthos et al., 2000; Miura, et al., 2003; Seo, et al., 2004). However, the efficiency of the DEX treatment varies depending on the initial cell source (Chadipiralla, et al., 2010). The exact intra-cellular mechanism through which dexamethasone treatments stimulate osteogenic differentiation is unknown.

\subsection{Retinoic acid}

RA is an oxidized form of Vitamin A. RA was first used to up-regulate osteoblast differentiation and proliferation with great success (Song, et al., 2005; Kawaguchi et al., 2005; Skillington et al., 2002; Choong et al., 1993), then later used to induce osteogenic stem cell differentiation (Malladi et al., 2006; San Miguel, et al., 1998). The exact intra-cellular mechanism through which retinoic acid treatments stimulate osteogenic differentiation is unknown.

\subsection{Bone morphogenic protein}

BMP is a crucial protein in the osteoconductive process (Einhorn, 2003; Dimitriou, et al., 2005; Kain \& Einhorn, 2005; Govender, et al., 2002). There are many variations of BMP, each with its own functionality; BMP-2 and BMP-7 have been shown to be crucial for bone maintenance. BMP-2 and RA have been shown to accelerate bone formation and osteoclast recruitment in vivo (Cowan, et al., 2005).

\subsection{Platelet derived growth factor}

Bone platelet derived growth factor is a dose-dependent bone formation enhancer (Thorwarth et al., 2006).

\section{Scaffolds}

For regenerative tissue engineering, cells can be expanded and differentiated in monolayer but must be delivered to the body in a 3-D scaffold. When designing a 3-D scaffold, it is 
important to take into account several key design elements such as the mechanical, chemical, and physiological properties of the scaffold, the environment it will be placed in, and the type of tissue it needs to support (Vacanti \& Vacanti, 2000). The scaffold must have the correct surface chemistry and structure for optimizing the cell-scaffold interaction. In this case, the cells must be able to adhere to and proliferate on the scaffold. The scaffold must be biocompatible with the cells that it will support, in this case stem cells, and it must be biocompatible with the environment where it will eventually be placed in the body Additionally, the scaffold needs to have pores large enough for the cells to reside within it without being dislodged (pore size), and it needs to have well interconnected pores so nutrients can diffuse to the cells (porosity/interconnectivity). Mechanical strength is necessary for creating structurally sound replacement bone. However, the ideal scaffold would degrade as the new tissue formed. Many factors can cause polymers to break down through hydrolysis and enzymatic cleavage. Furthermore, some scaffolds are functionalized to release key agents in the healing cascade. Unfortunately, the ideal scaffold has not yet been identified, as a multitude of factors must be considered. The best scaffold for regenerative tissue engineering will vary depending on the type of injury, type of repair, and the final desired outcome.

\subsection{Extracellular matrix substitutes}

In-vivo, cells are suspended in a 3D scaffold called the extracellular matrix (ECM), which provides the cells with both the mechanical support and nutrients necessary for their survival. For optimal modeling of in-vivo conditions, scaffolds consisting of hydroxyapatite, naturally found in the ECM, have been investigated; unfortunately (Vial, 2008; Mastrogiacomo, et al., 2005; Salgado et al., 2004), these scaffolds have low mechanical stability.

\subsection{Natural polymers}

Alternatively, natural polymers such as collagen, fibrinogen, chitosan, etc. have been investigated. Natural polymers are a popular choice, because they are biodegradable, bioactive, elicit a minimal immune response, and can be chemically versatile (Vial, 2008). Furthermore, researchers have shown that these polymers can be mineralized (Salgado et al., 2004), further mimicking the natural conditions of bone. Oftentimes, natural polymers can be formed by combining two components, thereby crosslinking the polymer to form a gel. In this case, the crosslinking agent and the cells could be injected into a bone healing site arthroscopically, thereby reducing the risk of infection from traditional open surgery.

\subsection{Synthetic polymers}

In addition, synthetic polymers can also be utilized to form a 3-D scaffold through various techniques such as fiber bonding, emulsion freeze drying, solvent casting/ particulate leaching, high-pressure processing, gas foaming/ particle leaching, thermally induced phase separation, electrospinning, and rapid prototyping (Chung \& Park, 2007; Tsang \& Bhatia, 2004). Each is useful in forming a viable scaffold; however, the ideal scaffold must ultimately be selected based on the final desired outcome of the tissue repair. Ultimately, no synthetic manufactured scaffold is a perfect replacement for natural bone grafts. 


\subsection{Organ printing}

Organ printing is a branch of regenerative medicine in which $3 \mathrm{D}$ living tissues are constructed from single cells printed with a thermo-reversible gel. Mironov et al (Mironov et al., 2003) define organ printing as 'a rapid prototyping computer-aided 3D printing technology, based on using layer by layer deposition of cell and/or cell aggregates into a 3D gel with sequential maturation of the printed construct into perfused and vascularized living tissue or organ.' Organ printing takes place in 3 distinct phases: preprocessing, processing, and postprocessing. In preprocessing, a computer model of the tissue is constructed based on deficiencies observed via MRI or CT-scans. The processing is the actual layer by layer printing (placement) of cells in the $3 \mathrm{D}$ environment. The postprocessing consists of tissue perfusion, directing tissue maturation, and, finally biomechanical conditioning. If successful, organ printing may prove to be a valuable alternative form of regenerative medicine with a significantly decreased tissue maturation period compared to traditional tissue engineering approaches.

\section{In vitro studies of bone tissue engineering - bioreactor design}

It has been demonstrated that a combination of biochemical agents and mechanical forces can be used to accelerate the production of a desired phenotype (Freed, et al., 2006). Mechanotransduction refers to the biochemical cascade that converts a mechanical stimulus into chemical activity; in other words, the application of mechanical stress can guide stem cells to undergo guided differentiation (Haudenschild et al., 2009; Wang \& Thampatty, 2008). However, the application of mechanical stresses cannot be arbitrary, rather biomechanical models must be established to mimic in-vivo force patterns in an in-vitro bioreactor (Burdick \& Vunjak-Novakovic, 2009; Butler, et al., 2008). The most important consideration in bioreactor design is mimicking in-vivo conditions, thereby mechanically conditioning tissue before it is transplanted into the body.

\subsection{Mechanical strain}

Bone specifically requires mechanical stimulation to maintain its strength. Astronauts who spend extended periods of time in space experience severe bone mineral loss due to the zero gravity conditions (Sikavitsas et al., 2001). Mechanical strain can be applied directly by compressing, stretching, or bending cell/scaffold constructs. Compressive bioreactors have been shown to increase both proteoglycan and matrix deposition by MSCs (Burger et al., 1992; Wartella \& Wayne, 2009). Uniaxial stretching of human osteoblastics cells has been shown to increase cell proliferation and increase gene expression of ALP, osteocalcin (OCN), osteopontin (OPN), and collagen type I (Col1) (Ignatius, et al., 2004; Ignatius, et al., 2005). On the other hand, cyclic stretching results in only increased proliferation (Neidlinger-Wilke et al., 1994). With MSCs, 4-point bending bioreactors can increase ALP activity levels, increase mineralized matrix production, and increase gene expression of ALP and OPN (Mauney, et al., 2004).

\subsection{Hydrodynamic shear stress}

In addition to mechanical stimulation, another important consideration is nutrient supply; cells placed in a bioreactor must have access to fresh nutrients from media, as well as a 
means for removal of cellular waste (Rauh et al., 2011). Hydrodynamic shear stresses can be applied via spinner flask, rotation, or perfusion bioreactors: For spinner flask bioreactor systems, convective forces are applied by a stirrer which moves the media around the cell/scaffold construct. Studies using MSCs in spinner flasks have shown increased cellular proliferation, increased ALP activity levels, and increased gene expression of ALP, OPN, BSP, and Col1 (Kim H. , et al., 2007; Meinel, et al., 2004a; Mygind, et al., 2007; Stiehler, et al., 2009). Rotating bioreactor systems use laminar flow by rotating a vessel along the horizontal surface to create shear stress. Human ASCs and BM-MSCs have shown an increase in cellular proliferation and respective increases in ALP activity and OCN activity when cultured in rotating bioreactors (Diederichs, et al., 2009; Pound et al., 2007). Furthermore, additional testing in rats also shows an increase in cellular distribution and extracellular matrix formation (Goldstein et al., 2001; Qiu et al., 1999). Finally, perfusion driven bioreactors address nutrient diffusion deficiencies by providing fresh media and creating fluid shear stress. Perfusion bioreactors increase cellular proliferation and distribution and cell viability in the center of cell/ scaffold constructs (Bernhardt et al., 2008; Frohlich, et al., 2010; Grayson, et al., 2008; Jagodzinski, et al., 2008; Meinel, et al., 2004b; Rauh et al., 2011).

\section{In vivo study of bone tissue engineering}

Currently, there is no consensus on the best clinical model for engineered bone tissue. Comparable to how transplanted cells that have been pre-differentiated in vitro form bonelike tissues better than undifferentiated transplanted cells (Cowan, et al., 2005; Conjero, et al., 2006), engineered bone tissue that has been allowed to develop and mature in vitro promotes better bone healing after implantation than cell/ scaffold constructs that were not cultivated (Meinel, et al., 2004a; Meinel, et al., 2004b; Frohlich, et al., 2008). To assess the osteogenic potential of a cell/ scaffold construct, human cellular constructs were implanted subcutaneously in immunodeficient mice. Under these conditions, cells can develop into bone tissue in vivo (Kuznetsov, et al., 1997). Engineered bone tissue constructs have been used to repair load bearing and non-load bearing critical-size defects in various rodent models (Ohgushi et al., 1989; Puelacher et al., 1996; Bruder, et al., 1998a). Naturally criticalsized defects exhibit incomplete repair due to limited number of autologous stem cells available for use in the repair process. Research on larger animal models such as sheep and dogs has shown repair of critical-sized defects was enhanced by the use of stem cells in engineered bone tissue (Bruder et al., 1998b; He, et al., 2007; Kon, et al., 2000; Petite, et al., 2000; Shang, et al., 2001; Viateau, et al., 2007).

\section{Conclusions and future directions}

Regenerative tissue engineering addresses the discrepancy between the available transplantable donor tissue and the need. There are many choices for both cells and scaffolds, and the best combination will vary depending on the type of injury, type of repair, and the final desired outcome. Stem cells are an ideal cell source for bone regenerative tissue engineering applications, because they are capable of self- renewal, are undifferentiated, and can give rise to specialized tissue like bone. As our understanding of these cells improves, new engineering approaches (such as the 3D organ printer) will be developed to optimize the production of functional tissues. 


\section{References}

Amado, L; Saliaris, A; Schuleri, K; St John, M; Xie, J; Cattaneo, S; Durand, D; Fitton, T; Kuang, J; Stewart, G; Lehrke, S; Baumgartner, W; Martin, B; Heldman, A; Hare, J. (2005). Cardiac repair with intremyocardial injection of allogenic mesenchymal stem cells after myocardial infarction. Proc Natl Acad Sci USA, 102(32), 11474-11479.

Amit, M., \& Itskovitz-Eldor, J. (2002). Derivation and spontaneous differentiation of human embryonic stem cells. J Anat, 200(Pt3), 225-232.

Ballen, K., Barker, J., Stewart, S., Greene, M., Lane, T., \& Transplantation, A. S. (2008). Collection and preservation of cord blood for personal use. Biol Blood Marrow Transplant, 14(3), 356-363.

Batouli, S; Miura, M; Brahim, J; Tsutsui, T; Fisher, L; Gronthos, S; Robey, P; Shi, S. (2003). Comparison of stem-cell-mediated osteogenesis and dentinogenesis. J Dent Res, 82(12), 976-981.

Bernhardt, A., Lode, A., Boxberger, S., Pompe, W., \& Gelinsky, M. (2008). Mineralised collagen-an artificial, extracellular bone matrix-- improves osteogenic differentiation of bone marrow stromal cells. J Mater Sci Mater Med, 19(1), 269-275.

Bielby, R., Boccaccini, A., Polak, J., \& Buttery, L. (2004). In vitro differentiation and in vivo mineralization of osteogenic cells derived from human embryonic stem cells. Tissue Eng, 10(9-10), 1518-1525.

Biswas, A., \& Hutchins, R. (2007). Embryonic Stem Cells. Stem Cells and Development, 16, 213221.

Bruder, S., Kraus, K., Goldberg, V., \& Kadiyala, S. (1998a). The effect of implants loaded with autologous mesenchymal stem cells on the healing of canine segmental bone defects. J Bone Joint Surg Am, 80(7), 985-996.

Bruder, S., Kurth, A., Shea, M., Hayes, W., Jaiswal, N., \& Kadiyala, S. (1998b). Bone regeneration by implantation of purified, culture-expanded human mesenchymal stem cells. J Orthop Res, 16(2), 155-162.

Brunstein, C., Setubal, D., \& Wagner, J. (2007). Expanding the role of umbilical cord blood transplantation. Br J Haematol, 137(1), 20-35.

Buckwalter, J., \& Hunziker, E. (1996). Healing of bones, cartilages, tendons, and ligaments: a new era. Lancet, 348 Suppl 2: sII18, 21-28.

Burchardt, H. (1983). The biology of bone graft repair. Clin Orthop Relat Res, 28-42.

Burdick, J., \& Vunjak-Novakovic, G. (2009). Engineered Microenvironments for Controlled Stem Cell Differentiation. Tissue Eng Park A, 15(2), 205-219.

Burger, E., Klein-Nulend, J., \& Veldhuijzen, J. (1992). Mechanical stress and osteogenesis in vitro. J Bone Miner Res, 7 Suppl, S397-S401.

Butler, D., Juncosa-Melvin, N., Boivin, G., Galloway, M., Shearn, J., Gooch, C., \& Awad, H. (2008). Functional tissue engineering for tendon repair: A multidisciplinary strategy using mesenchymal stem cells, bioscaffolds, and mechanical stimulation. J Orthop Res, 26(1), 1-9.

Campagnoli, C., Roberts, I., \& Kumar, S. (2001). Identification of Mesenchymal stem/ progenitor cells in human first-trimester blood, liver, bone and bone marros. Blood, 98, 2396-2402.

Cassidy, C; Jupiter, J; Cohen, M; Delli-Sant, M; Leinberry, C; Husband, J; Ladd, A; Seitz, W; Constanz, B. (2003). Norian SRS cement compared with conventional fixation in 
distal radial fractures. A randomized study. J Bone Joint Surg Am, 85-A(11), 21272137.

Chadipiralla, K., Yochim, J., Bahuleyan, B., Huang, C., Garcia-Godoy, F., Murray, P., \& Stelnicki, E. (2010). Osteogenic differentiation of stem cells derived from human periodontal ligaments and pulp of human exfoliated deciduous teeth. Cell Tissue Res.

Chai, Y; Jiang, X; Ito, Y; Bringas, P Jr; Han, J; Rowitch, D; Soriano, P; MaMahon, A; Sucov, H. (2000). Fate of the mammalian cranial neural crest during tooth and mandibular morphogenesis. Development, 127(8), 1671-1679.

Choong, P., Martin, T., \& Ng, K. (1993). Effects of ascorbic acid, calcitriol, and retinoic acid on the differentiation of preosteoblasts. J Orthop Res, 11, 638-647.

Chung, H. J., \& Park, T. G. (2007). Surface engineered and drug releasing pre-fabricated scaffolds for tissue engineering. Advanced Drug Delivery Reviews, 59, 249-262.

Conjero, J., Lee, J., Parrett, B., Terry, M., Wear-Maggitti, K., Grant, R., \& Breitbart, A. (2006). Repair of palatal bone defects using osteogenically differentiated fat-derived stem cells. Plast Reconstr Surg, 117.

Cowan, C; Aalami, O; Shi, Y; Chou, Y; Mari, C; Thomas, R; Quarto, N; Nacamuli, R; Contag, $\mathrm{C}$; $\mathrm{Wu}, \mathrm{B}$; Longaker, M. (2005). Bone morphogenetic protein 2 and retinoic acid accelerate in vivo bone formation, osteoclast recruitment, and bone turnover. Tissue Eng, 11, 645-658.

Cowan, C; Shi, Y; Aalami, O; Chou, Y; Mari, C; Thomas, R; Quarto, N; Contaq, C; Wu, B; Longaker, M. (2004). Adipose-derived adult stromal cells heal critical-size mouse calvarial defects. Nat Biotechnol, 22(5), 560-567.

Diederichs, S., Roker, S., Marten, D., Peterbauer, A., Scheper, T., van Griensven, M., \& Kasper, C. (2009). Dynamic cultivation of human mesenchymal stem cells in a rotating bed bioreactor system based on the Z RP platform. Biotechnol Prog, 25(6), 1762-1771.

Dimitriou, R., Dahabreh, Z., Katsoulis, E., Matthews, S., Branfoot, T., \& Giannoudis, P. (2005). Application of recombinant BMP-7 on persistent upper and lower limb nonunions. Injury, 35(Suppl 4), S51-9.

Einhorn, T. (2003). Clinical applications of recombinant human BMPs: early experience and future development. J Bone Joint Surg Am, 85-A, Suppl 3:82-8.

Fox, 1 S. I. (2001). Human Physiology (7 ed.). New York, United States of America: McGrawHill Higher Education.

Freed, L; Guilak, X; Gray, M; Tranquillo, R; Holmes, J; Radisic, M; Sefton, M; Kaplan, D; Vunjak-Novakovic. (2006). Advanced tools for tissue engineering: scaffolds, bioreactors, and signaling. Tissue Eng, 12(12), 3285-3305.

Frohlich, M., Grayson, W., Marolt, D., Gimble, J., Kregar-Velikonja, N., \& VunjakNovakovic, G. (2010). Bone grafts engineered from human adipose-derived stem cells in perfusion bioreactor culture. Tissue Eng Part A, 16(1), 179-189.

Frohlich, M., Grayson, W., Wan, L., Marolt, D., Drobnic, M., \& Vunjak-Novakovic, G. (2008). Tissue engineered bone grafts: biological requirements, tissue culture and clinical relevance. Curr Stem Cell Res Ther, 3(4), 254-264.

Gay, I., Chen, S., \& MacDougall, M. (2007). Isolation and characterization of multipotent human periodontal ligament stem cells. Orthod Craniofac Res, 10, 149-160. 
Goldstein, A., Juarez, T., Helmke, C., Gustin, M., \& Mikos, A. (2001). Effect of convection on osteoblastic cell growth and function in biodegradable polymer foam scaffolds. Biomaterials, 22(11), 1279-1288.

Govender, S; Csimma, C; Genant, H; Valentin-Opran, A; Amit, Y; Arbel, R; Aro, H; Atar, D; Bishay, M; Borner, MG; Chiron, P; Choong, P; Cinats, J; Courtenay, B; Feibel, R; Geulette, B; Gravel, C; Haas, N; Raschke, M; Hammacher, E; van her Velde, D; Hardy, P; M, Holt; Josten, C; Kettlerl, RL; Lindeque; B; Lob, G; Mathevon, H; McCoy, G; Marsh, D; Miller, R; Munting, E; Oevre, S; Nordsletten, L; Patel, A; Pohl, A; Rennie, W; Reynders, P; Rommens, PM; Rondia, J; Rossouw, WC; Daneel, PJ; Ruff, S; Ruter, A; Santavirta, S; Schildhauer, TA; Gekle, C; Schnettler, R; Segal, D; Seiler, H; Snowdowne, RB; Stapert, J; Taglag, G; Verdonk, R; Vogels, L; Weckbach, A; Wentzensen, A; Wisniewski, T; BMP-1 Evaluation in Surgery for Tibial Trauma, (BESTT) Study Group (2002). Recombinant human bone morphogenetic protein-2 for treatment of open tibial fractures:a prospective, controlled, randomized study of four hungrady and fifty patients. J Bone Joint Surg Am, 84-A(12), 2123-2134.

Grayson, W., Bhumiratana, S., Cannizzaro, C., Chao, P., Lennon, D., Caplan, A., \& VunjakNovakovic, G. (2008). Effects of initial seeding density and fluid perfusion rate on formation of tissue-engineered bone. Tissue Eng Part A, 14(11), 1809-1820.

Gronthos, S., Mankani, M., Brahim, J., Robey, P., \& S, S. (2000). Postnatal human dental pulp stem cells (DPSCs) in vitro and in vivo. Proc Natl Acad Sci USA, 97, 13625-13630.

Haudenschild, A., Hsieh, A., Kapila, S., \& Lotz, J. (2009). Pressure and distortion regulate human mesenchymal stem cell gene expression. Ann Biomed Eng, 37(3), 492-502.

He, Y., Zhang, Z., Zhu, H., Qiu, W., Jiang, X., \& Guo, W. (2007). Experimental study on reconstruction of segmental mandible defects using tissue engineered bone combined bone marrow stromal cells with three-dimensional tricalcium phosphate. J Craniofac Surg, 18(4), 800-805.

Heinegard, D., \& Oldberg, A. (1989). Structure and biology of cartilage and bone matrix noncollagenous macromolecules. FASEB J, 3(9), 2042-2051.

Heins, N; Englund, M; Sjoblom, C; Dahl, U; Tonning, A; Bergh, C; Lindahl, A; Hanson, C; Semb, H. (2004). Derivation, characterization, and differentiation of human embryonic stem cells. Stem Cells, 22(3), 367-376.

Huang, C.-Y. C., Pelaez, D., Bendala, J. D., Garcia-Godoy, F., \& Cheung, H. S. (2009). Plasticity of stem cells derived from adult periodontal ligament. Regen Med, 4(6).

Huang, G.-J., Gronthos, S., \& Shi, S. (2009). Mesenchymal Stem Cells Derived from Dental Tissues vs. Those from Other Sources: Their Biology and Role in Regenerative Medicine. Journal of Dental Research, 88(9), 792-806.

Huysseune, A., \& Thesleff, I. (2004). Continuous tooth replacement: the possible involvement of epithelial stem cells. Bioessays, 26(6), 665-671.

Ignatius, A., Blessing, H., Liedert, A., Kaspar, D., Kreja, L., Friemert, B., \& Claes, L. (2004). Effects of mechanical strain on human osteoblastic precursor cells in type I collagen matrices. Orthopade, 33(12), 1386-1393.

Ignatius, A; Blessing, H; Liedert, A; Schmidt, C; Neidlinger-Wilke, C; Kaspar, D; Friemert, B; Claes, L. (2005). Tissue engineering of bone: effects of mechanical strain on osteoblastic cells in type I collagen matrices. Biomaterials, 26(3), 311-318. 
Isaka, J; Ohazama, A; Kobayashi, M; Nagashima, C; Takiguchi, T; Kawasaki, H; Tachikawa, T; Hasegawa, K. (2001). Participation of periodontal ligament cells with regeneration of alveolar bone. J Periodontol, 72(3), 314-323.

Itskovitz-Eldor, J; Schuldiner, M; Karsenti, D; Eden, A; Yanuka, O; Amit, M; Soreq, H; Benvenisty, N. (2000). Differentiation of human embryonic stem cells into embryoid bodies compromising the three embryonic germ layers. Mol Med, 6(2), 88-95.

Jagodzinski, M; Breibart, A; Wehmeier, M; Hesse, E; Haasper, C; Krettek, C; Zeichen, J; Hankemeier, S. (2008). Influence of perfusion and cyclic compression on proliferation and differentiation of bone marrow stromal cells in 3-dimensional culture. J Biomech, 41(9), 1885-1891.

Kain, M., \& Einhorn, T. (2005). Recombinant human bone morphogenetic proteins in the treatment of fractures. Foot Ankle Clin, 10(4), 639-50, viii.

Kalfas, I. (2001). Principles of bone healing. Neurosurg Focus, 10(4), E1.

Kawaguchi, J., Mee, P., \& Smith, A. (2005). Osteogenic and chondrogenic differentiation of embryonic stem cells in response to specific growth factors. Bone, 36, 758-769.

Kerkis, I; Kerkis, A; Dozortsev, D; Stukart-Parsons, G; Gomes Massironi, SM Pereira, L; Caplan, A; Cerruti, H. (2006). Isolation and characterization of a population of immature dental pulp stem cells expressing OCT-4 and other embryonic stem cell markers. Cells Tissues Organs, 184(3-4), 105-116.

Kern, S., Eichler, H., Stoeve, J., Kluter, H., \& Bieback, K. (2006). Comparative analysis of mesenchymal stem cells from bone marrow, umbilical cord blood, or adipose tissue. Stem Cells, 24(5), 1294-1301.

Khan, M., Sahibzada, A., Khan, M., Sultan, S., Younas, M., \& Khan, A. (2005). Outcome of plating, bone grafting and shortening of non-union humeral diaphyseal fracture. $J$ Ayub Med Coll Abbottabed, 17(2), 44-46.

Kim, H., Kim, U., Leisk, G., Bayan, C., Georgakoudi, I., \& Kaplan, D. (2007). Bone regeneration on macroporous aqueous-derived silk 3-D scaffolds. Macromol Biosci, 7(5), 643-655.

Kim, Y., Kim, H., Cho, H., Bae, Y., Suh, K., \& Jung, J. (2007). Direct comparison of human mesenchymal stem cells derived from adipose tissues and bone marrow in mediating neovascularization in response to vascular ischemia. Cell Physiol Biochem, 20(6), 867-876.

Kneser, U., Schaefer, D., Polykandriotis, E., \& Horch, R. (2006). Tissue engineering of bone: the reconstructive surgeon's point of view. J Cell Mol Med, 10(1), 7-19.

Knoepfler, P. S. (2009). Deconstructing Stem Cell Tumorigenicity: A Roadmap to Safe Regenerative Medicine. Stem Cells, 27(5), 1050-1056.

Knowles, B., Aden, D., \& Solter, D. (1978). Monoclonal antibody detecting a stage-specific embryonic antigen (SSEA-1) on preimplantation mouse embryos and teratocarcinoma cells. Curr Top Microbiol Immunol, 81, 51-53.

Kon, E; Muraglia, A; Corsi, A; Bianco, P; Marcacci, M; Martin, I; Boyde, A; Ruspantini, I; Chistolini, P; Rocca, M; Giardino, R; Cancedda, R; Quarto, R. (2000). Autologous bone marrow stromal cells loaded onto porous hydroxyapatite ceramic accelerate bone repair in critical-size defects of sheep long bones. J Biomed Mater Res, 49(3), 328-337. 
Kuznetsov, S., Krebsback, P., Satomura, K., Kerr, J., Riminucci, M., Benayahu, D., \& Robey, P. (1997). Single-colony derived strains of human marrow stromal fibroblasts form bone after transplantation in vivo. J Bone Miner Res, 12(9), 1335-1347.

Laino, G; d'Aquino, R; Graziano, A; Lanza, V; Carinci, F; Naro, F; Pirozzi, G; Papaccio, G. (2005) A new population of human adult dental pulp stem cells: a useful source of living autologous fibrous bone tissue (LAB). J Bone Miner Res, 20(8), 1394-1402.

Le Douarin, N., Creuzet, S., Couly, G., \& Dupin, E. (2004). Neural crest cell plasticity and its limits. Development, 131(19), 4637-4650.

Lebkowski, J., Gold, J., Xu, C., Funk, W., Chiu, C., \& Carpenter, M. (2001). Human embryonic stem cells: culture, differentiation, and genetic modification for regenerative medicine applications. Cancer J, 7 Suppl 2, S83-S93.

Levi, B., \& Longaker, M. (2011). Concise review: adipose-derived stromal cells for skeletal regenerative medicine. Stem Cells, 29(4), 576-582.

Lewis, G. (1997). Properties of acrylic bone cement: state of the art review. J Biomed Mater Res, 38(2), 155-182.

Liu, G., Ye, X. Z., Li, Y., Sun, J., Cui, L., \& Cao, Y. (2011). Osteogenic differentiation of GFPlabeled human umbilical cord blood derived mesenchymal stem cells after cryopreservation. Cryobiology.

Malladi, P., Xu, Y., Yang, G., \& Longaker, M. (2006). Functions of vitamin D, retinoic acid, and dexamthasone in mouse adipose-derived mesenchymal cells. Tissue Eng, 12, 2031-2040.

Mankin, H., Hornicek, F., \& Raskin, K. (2005). Infection in massive bone allografts. Clin Orthop Relat Res(432), 210-216.

Mastrogiacomo, M., Muraglia, A., Komlev, V., Peyrin, F., Rustichelli, R., Crovace, A., \& Cancedda, R. (2005). Tissue engineering of bone: search for a better scaffold. Orthod Craniofac Res, 8(4), 277-284.

Mauney, J; Sjostorm, S; Blumberg, J; Horan, R; O'Leary, J; Vunjak-Novakovic, G; Volloch, V; Kaplan, DL. (2004). Mechanical stimulation promotes osteogenic differentiation of human bone marrow stromal cells on 3-D partially demineralized bone scaffolds in vitro. Calcif Tissue Int, 74(5), 458-468.

Meinel, L; Karageorgiou, V; Fajardo, R; Snyder, B; Shinde-Patil, V; Zichner, L; Kaplan, D; Langer, R; Vunjak-Novakovic, G. (2004a). Bone tissue engineering using human mesenchymal stem cells: effects of scaffold material and medium flow. Ann Biomed Eng, 32(1), 112-122.

Meinel, L., Karageorgiou, V., Hofmann, S., Fajardo, R., Snyder, B., Li, C., Kaplan, D. (2004b). Engineering bone-like tissue in vitro using human bone marrow stem cells and silk scaffolds. J Biomed Mater Res A, 71(1), 25-34.

Meissner, A., Wernig, M., \& Jaenisch, R. (2007). Direct reprogramming of genetically unmodifies fibroblasts into pluripotent stem cells. Nat Biotechnol, 25(10), 1177-1181.

Mironov, V., Boland, T., Trusk, T., Forgacs, G., \& Markwald, R. R. (2003). Organ printing: computer-aided jet-based 3D tissue engineering. TRENDS in Biotechnology, 21(4), 157-161.

Miura, M., Gronthos, S., Zhao, M., Lu, B., Fisher, L. W., Robey, P. G., \& Shi, S. (2003). SHED: stem cells from human exfoliated deciduous teeth. Proc Natl Acad Sci USE, 100(10), 5807-5812. 
Muh, E., Zimmermann, J., Kneser, U., Marquardt, J., Mulhaupt, R., \& Stark, B. (2002). Lysineurethanedimethacrylate--a novel generation of amino acid based monomers for bone cements and tissue repair. Biomaterials, 23(14), 2849-2854.

Mygind, T; Stiehler, M; Baatrup, A; Li, H; Zou, X; Flybjerg, A; Kassem, M; Bunger, C. (2007). Mesenchymal stem cell ingrowth and differentiation on coralline hydroxyapatite scaffolds. Biomaterials, 28(6), 1036-1047.

Neidlinger-Wilke, C., Wilke, H., \& Claes, L. (1994). Cyclic stretching of human osteoblasts affects proliferation and metabolism: a new experimental method and its application. J Orthop Res, 12(1), 70-78.

Odorico, J., Kaufman, D., \& Thomson, J. (2001). Multilineage differentiation from human embryonic stem cell lines. Stem Cells, 19(3), 193-204.

Ogston, N., Harrison, A., Cheung, H., Ashton, B., \& Hampson, G. (2002). Dexamethasone and retinoic acid differentially regulate growth and differentiation in an immortalised human clonal bone marrow stromal cell line with osteoblastic characteristics. Steroids, 67, 895-906.

Ohgushi, H., Goldberg, V., \& Caplan, A. (1989). Repair of bone defects with marrow-cells and porous ceramic. Experiments in rats. Acta Orthop Scand, 60(3), 334-339.

Okita, K., Ichisaka, T., \& Yamanaka, S. (2007). Generation of germline-compotent induced pluripotent stem cells. Nature, 448(7151), 313-317.

Park, J., Kim, S., Oh, E., Moon, S., Roh, S., Kim, C., \& Yoon, H. (2003). Establishment and maintenance of human embryonic stem cells on STO, a permanently growing cell line. Biol Reprod, 69(9), 2007-2014.

Petite, H; Viateau, V; Bensaid, W; Meunier, A; de Pollak, C; Bourguignon, M; Oudina, K; Sedel, L; Guillemin, G. (2000). Tissue-engineered bone regeneration. Nat Biotechnol, 18(9), 959-961.

Pittenger, MF; Mackay, AM; Beck, SC; Jaiswal, RK; Douglas, R; Mosca, JD; Moorman, MA; Simonetti, DW; Craig, S; Marshak, DR. (1999). Multilineage potential of adult human mesenchymal stem cells. Science, 284, 143-147.

Pound, J., Green, D., Roach, H. M., \& Oreffo, R. (2007, Jun). An ex vivo model for chondrogenesis and osteogenesis. Biomaterials, 28(18), 2839-2849.

Probst, A., \& Spiegel, H. (1997). Cellular mechanisms of bone repair. J Invest Surg, 10(3), 77-86.

Puelacher, W., Vacanti, J., Ferraro, N., Schloo, B., \& Vacanti, C. (1996). Femoral shaft reconstruction using tissue-engineered growth of bone. Int J Oral Maxillofac Surg, 25(3), 223-228.

Qiu, Q., Ducheyne, P., \& Ayyaswamy, P. (1999). Fabrication, characterization and evaluation of bioceramic hollow microspheres used as microcarriers for 3-D bone tissue formation in rotating bioreactors. Biomaterials, 20(11), 989-1001.

Rauh, J., Milan, F., Gunther, K., \& Stiehler, M. (2011). Bioreactor Systems for Bone Tissue Engineering. Tissue Eng Part B Rev, 17(4), 263-280.

Salgado, A., Coutinho, O., \& Reis, R. (2004). Bone tissue engineering: state of the art and future trends. Macromol Biosci, 4(8), 743-765.

San Miguel, S., Goseki-Sone, M., Sugiyama, E., Watanabe, H., Yanagishita, M., \& Ishikawa, I. (1998). The effects of retinoic acid on alkaline phosphatase activity and tissue-nonspecific alkaline phosphatase gene expression in human periodontal ligament cells and gingival fibroblasts. J Periodontal Res, 33, 428-433. 
Schroeder, J., \& Mosheiff, R. (2011) Tissue engineering approaches for bone repair: Concepts and evidence. Injry, 42(6), 609-613.

Schugar, R; Chireleison, S; Wescoe, K; Schmidt, B; Askew, Y; Nance, J; Evron, J; Peault, B; Deasy, B. (2009). High harvest yield, high expansion, and phenotype stability of CD146 mesenchymal stromal cells from whole primitive human umbilical cord tissue. J Biomed Biotechnol, 789526.

Seo, B; Miura, M; Gronthos, S; Bartold, P, Batouli, S; Brahim, J; Young, M; Robey, P; Wang, C; Shi, S. (2004). Investigation of multipotent postnatal stem cells from human periodontal ligament. Lancet, 364, 149-155.

Seo, B; Sonoyama, W; Yamaza, T; Coppe, C; Kikuiri, T; Akiyama, K; Lee, J; Shi, S. (2007). SHED repair critical-size calvarial defects in mine. Oral Diseases, 14, 428-434.

Shang, Q., Wang, Z., Liu, W., Shi, Y., Cui, L., \& Cao, Y. (2001). Tissue-engineered bone repair of sheep cranial defects with autologous bone marrow stromal cells. J Craniofac Surg, 12(6), 586-595.

Shier, D., Butler, J., \& Lewis, R. (2002). Hole's Human Anatomy \& Physiology (9 ed.). New York, NY: Mc-Graw-Hill.

Sikavitsas, V., Temenoff, J., \& Mikos, A. (2001). Biomaterials and bone mechanotransduction. Biomaterials, 22(19), 2581-2593.

Skillington, J., Choy, L., \& Derynck, R. (2002). Bone morphogenic protein and retinoic acid signaling cooperate to induce osteoblast differentiation of preadipocytes. J Cell Biol, 159, 135-146.

Song, H., Nacamuli, R., Xia, W., Bari, A., Shi, Y., Fang, T., \& Longaker, M. (2005). High-dose retinoic acid modulates rat calvarial osteoblast biology. J Cell Physiol, 202, 255-262.

Stiehler, M., Bunger, C., Baatrup, A., Lind, M., Kassem, M., \& Mygind, T. (2009). Effect of dynamic 3-D culture on proliferation, distribution, and osteogenic differentiation of human mesenchymal stem cells. J Biomed Mater Res A, 89(1), 96-107.

Takahashi, K., \& Yamanaka, S. (2006). Induction of pluripotent stem cells from mouse embryonic and adult fibroblast cultures by defined factors. Cell, 126(4), 663-676.

Takahashi, K., Tanabe, K., Ohnuki, M., Narita, M., Ichisaka, T., Tomoda, K., \& Yamanaka, S. (2007). Induction of pluripotent stem cells from adult human fibroblasts by defined factors. Cell, 131(5), 861-872.

Thomson, J., \& Marshall, V. (1998a). Primate embyonic stem cells. Curr Top Dev Biol, 38, 133165.

Thomson, J., Itskovitz-Eldor, J., Shapiro, S., Waknitz, M., Swiergiel, J., Marshall, V., \& Jones, J. (1998b). Embryonic stem cell lines derived from human blastocysts. Science, 282(5391), 1145-1147.

Thorwarth, M., Wehrhan, F., Schultze-Mosqau, S., Wiltfang, J., \& Schlegel, K. (2006). PRP modulated expression of bone matrix proteins in vivo without long-term effects on bone formation. Bone, 38(1), 30-40.

Tsang, V. L., \& Bhatia, S. N. (2004). Three-dimensional tissue fabrication. Advanced Drug Delivery Reviews, 56, 1635-1647.

Vacanti, C., \& Vacanti, J. (2000). The science of tissue engineering. Orthop Clin North Am, 31(3), 351-356.

Vial, X. (2008). Gelatin Based Scaffolds for Bone Tissue Engineering. Open Access Theses, Paper 163. Retrieved from http:/ / scholarlyrepository.miami.edu/oa_theses/163 
Viateau, V; Guillemin, G; Bousson, V; Oudina, K; Hannouche, D; Sedel, L; LogeartAvramoglou, D; Petite, H. (2007). Long-bone critical-size defects treated with tissue-engineered grafts: a study on sheep. J Orthop Res, 25(6), 741-749.

Wagner, W; Wein, F; Seckinger, A; Frankhauser, M; Wirkner, U; Krause, U; Blake, J; Schwager, C; Echstein, V; Ansorge, W; Ho, A. (2005). Comparative characterisitcs of mesenchymal stem cells from human bone marrow, adipose tissue, and umbilical cord blood. Exp Hematol, 33(11), 1402-1416.

Wang, J., \& Thampatty, B. (2008). Mechanobiology of adult and stem cells. Int Rev Cell Mol Biol, 271, 301-346.

Wartella, K., \& Wayne, J. (2009). Bioreactor for biaxial mechanical stimulation to tissue engineered constructs. J Biomech Eng, 131(4), 044501,1-044501,5.

Young, H; Steele, T; Bray, R; Hudson, J; Floyd, J; Hawkins, K; Thomas, K; Austin, T; Edwards, C; Cuzzourt, J; Duenzl, M; Lucas, P; Black, A Jr. (2001). Human reserve pluripotent mesenchymal stem cells are present in the connective tissues of skeletal muscle and dermis derived from fetal, adults, and geriatric donors. Anat Rec, 264, 51-62.

Yu, J; Vodyanik, M; Smuga-Otto, K; Antosiewicz-Bourget, J; Frane, J; Tian, S; Nie, J; Jonsdottir, G; Ruotti, V; Stewart, R; Slukvin, I; Thomson, J. (2007). Induced pluripotent stem cell lines derived from human somatic cells. Science, 318(5858), 1917-1920.

Zijderveld, S., Zerbo, I., van den Bergh, J., Schulten, E., \& ten Bruggenkate, C. (2005). Maxillary sinus floor augmentation using a beta-tricalcium phosphate (Cerasorb) alone compared to autogenous bone grafts. Int J Oral Maxillofac Implants, 20(3), 432440.

Zuk, P; Zhu, M; Mizuno, H; Huang, J; Futrell, J; Katz, A; Benhaim, P; Lorenz, H; Hedrick, M. (2001). Multilineage cells from human adipose tissue: implications for cell-based therapies. Tissue Eng, 7, 211-228. 


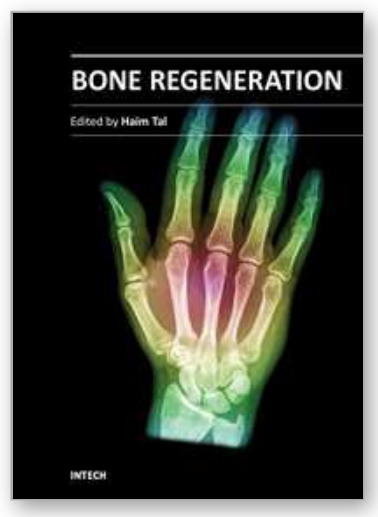

\author{
Bone Regeneration \\ Edited by Prof. Haim Tal
}

ISBN 978-953-51-0487-2

Hard cover, 340 pages

Publisher InTech

Published online 04, April, 2012

Published in print edition April, 2012

Bone is a specialized connective tissue, most prominently characterized by its mineralized organic matrix that imparts the physical properties that allow bone tissue to resist load, to support functional organs, and to protect highly sensitive body parts. Bone loss and bone damage may occur as a result of genetic conditions, infectious diseases, tumours, and trauma. Bone healing and repair, involves integrative activity of native tissues and living cells, and lends itself to the incorporation of naturally derived or biocompatible synthetic scaffolds, aimed at replacing missing or damaged osseous tissues. There are several modalities of bone regeneration including tissue engineering, guided bone regeneration, distraction ontogenesis, and bone grafting. This book concentrates on such procedures that may well be counted among the recent outstanding breakthroughs in bone regenerative therapy.

\title{
How to reference
}

In order to correctly reference this scholarly work, feel free to copy and paste the following:

Lauren Vernon, Lee Kaplan and Chun-Yuh Charles Huang (2012). Stem Cell Based Bone Tissue Engineering, Bone Regeneration, Prof. Haim Tal (Ed.), ISBN: 978-953-51-0487-2, InTech, Available from: http://www.intechopen.com/books/bone-regeneration/stem-cell-based-bone-tissue-engineering-

\section{INTECH}

open science | open minds

\section{InTech Europe}

University Campus STeP Ri

Slavka Krautzeka 83/A

51000 Rijeka, Croatia

Phone: +385 (51) 770447

Fax: +385 (51) 686166

www.intechopen.com

\section{InTech China}

Unit 405, Office Block, Hotel Equatorial Shanghai

No.65, Yan An Road (West), Shanghai, 200040, China

中国上海市延安西路65号上海国际贵都大饭店办公楼 405 单元

Phone: +86-21-62489820

Fax: +86-21-62489821 
(C) 2012 The Author(s). Licensee IntechOpen. This is an open access article distributed under the terms of the Creative Commons Attribution 3.0 License, which permits unrestricted use, distribution, and reproduction in any medium, provided the original work is properly cited. 